DOI 10.37882/2500-3682.2020.12.24

\title{
РЕФЛЕКСИЯ И ЗРЕЛОСТЬ ЛИЧНОСТИ
}

\section{REFLECTION AND PERSONAL MATURITY}

\section{A. Machukha \\ O. Vasilyeva}

Summary: The article presents the results of a research area of scientific interest and the purpose of which was to determine the place of reflection in the construct of mental and psychological health and maturity of the individual. Through in-depth analysis of research results presented in scientific research by both domestic and foreign scientists from different eras (Aristotle, J. Jaines, J. Lacan, J. Locke, V.A. Milovidov, Yu.A. Patsyukova, V.V. Savchuk and many others), revealed aspects of contextuality of reflection as a function that constructs consciousness, understanding the role of the social in the formation of reflection, the place and role of the 0ther in its formation, as well as certain qualitative characteristics of the specifics of reflection manifestations.

Keywords: reflection, personal maturity, psychological and mental health consciousness, Super-Ego.

\author{
Мачуха Александр Михайлович \\ Соискатель, Южный Федеральный Университет \\ aleksandrinfo@bk.ru \\ Васильева Ольга Семеновна \\ К.б.н., профессор, Южный Федеральный Университет \\ vos@sfedu.ru
}

Аннотация: В статье представлены результаты исследования сферой научного интереса и целью которого стало определение места рефлексии в конструкте психического и психологического здоровья и зрелости личности. Посредством глубокого анализа результатов исследований, представленных в научных изысканиях как отечественных, так и зарубежных ученых - представителей разных эпох (Аристотель, Дж. Джейнс, Ж. Лакан, Дж. Локк, В.А. Миловидов, Ю.А. Пацюкова, В.В. Савчук и многих др.), были раскрыты аспекты контекстности рефлексии как конструирующей сознание функции, понимания роли социального в становлении рефлексии, места и роли Другого в её становлении, а также отдельные качественные характеристики специфики проявлений рефлексии.

Ключевые слова: рефлексия, зрелость личности, психологическое и психическое здоровье, сознание, Супер-Эго.

\section{Введение}

2 удучи многомерным и одним из наиболее широких в своих проявлениях феноменов, рефлексия, так или иначе, с момента введения понятия в научный оборот, затрагивала и продолжает затрагивать умы множества ученых: в начале философов, затем психологов, а в настоящее время и представителей как смежных с этими направлениями человекознания, так и наук о мироустройстве. Здесь необходимо согласиться с тем пониманием, что иного, «внечеловеческого» мира для нас пока не известно, т.е. весь окружающий нас мир во- или о-человечен, таким образом, мы может быть и теоретически понимаем, как может, например, воспринимать свое «витальное пространство» фасеточным зрением стрекоза, но это понимание сугубо теоретическое, и «провести» такое понимание через наше собственное восприятие мира мы не сможем никогда. Мы создаем все новые и новые инструменты для познания мира, но и они являются «продолжением и «усилением» наших органов чувств, отражением степени развития нашего интеллекта, при этом весьма ограниченного предыдущими открытиями, и «перепрыгнуть» здесь мы не можем. Так, совершая гениальные открытия (например, законы механики и термодинамики), человечество еще долго проецирует их на совсем иные стороны своей жизни, непроизвольно вводя себя в заблуждения. При этом суть человеческой природы такова, что слишком революционные идеи могут в корне поколебать все устройство жизни человечества, и здесь уместен пример смены аподиктического понима- ния Бога («Бог во всех его земных и небесных творениях и сущих тварях») на апофатическое («Бог есть не это, не это и не это»), и, вообще, «обезглавливание бога» (Ф. Ницше), но «если бог умер, то умер и человек». Однако при этом человечество, так или иначе, в своей рефлексии приходит к истинам, выступающим первоосновными и постулирующими. При всей неопределенности и многосмысленности понятия «сознание» очевидным является, однако, то, что сознание как специфическое «выделение» человека из всей остальной природы невозможно без феномена рефлексии. Однако если у нас есть сознание как психическая реальность, то у каждого из нас проявления сознания качественно различны, т.е. уже они во многом определяют характеристики нашей личности (также крайне широкого и слабо определенного явления). Но тогда и проявления рефлексии у каждого из нас различны, но если речь идет о психическом и психологическом здоровье, о здоровье и зрелости личности, то ведя о них речь, нельзя не вести разговор и об уровне или качественных характеристиках рефлексии. При этом насколько позволяет судить анализ источников, тема качественных проявлений рефлексии в связи со зрелостью личности фактически не рассматривается.

\section{Теоретический анализ проблемы исследования}

Введение термина «рефлексия» в научный оборот связывают с именем «марбугского Платона» - мыслителя и энциклопедиста Рудольфа Гоклениуса, впервые опубликовавшего статью с названием «Reflexio» в фило- 
софском словаре, да и то упоминавшего рефлексию в качестве физического явления, буквально как «вращаться назад», или - «вращаться снова», а в переносном смысле «уклоняться, воздерживаться, униматься» в противовес «incitari» - «устремляться». Позже этот термин употребляется в оптике у Иоганна Микраэлиуса (словарь 1653 г.) для описания отражения света (соотношение углов падения и отражения), и здесь в термине очевидно присутствие «флексии» как отражающей поверхности. Однако, как на это обращает внимание В.В. Савчук [11] (предыдущие материалы также представлены из его работы), для Античности как колыбели западной научной мысли самонаблюдение было, в целом, несвойственно и соотносилось скорее с болезнью, чем с нормальным процессом осмысления: только сам человек может решить, болен он или нет, и именно его больная нога или голова заставляют привлечь внимание человека к себе; так же и в иных проявлениях мысль, обращенная на себя, расценивалась как нечто ненормальное. И здесь достаточно вспомнить «Илиаду», хотя и являющуюся, как сейчас считают, плодом труда разных авторов, и, кроме того, написанную (дописываемую) в разное время, но и в ней мы не находим рассуждений матросов о собственных переживаниях или воспоминаниях, но всегда о паттернах действия, на основе чего, в частности, Дж. Джейнс приходит к теории «двухпалатного ума», согласно которому в традиционном мышлении правое полушарие «воспринимало знаки судьбы» или «веления богов» (как бы приходящие извне), а левое - их исполняло [2], и отсюда (из аутичного шизофренического мышления) полное следование фатуму у древних греков. Однако и Платон, и Аристотель обращают внимание на то, что «ум может мыслить сам себя», но речь здесь скорее идет о «мышлении о мышлении», и не столько о рефлексии как о комплексном явлении сознания. Сколь близкое понимание рефлексии в этом контексте не «трогает» умы западных философов, по крайней мере, до начала XVII в., хотя идея «собой созерцай себя» изначально присутствует уже в даосизме [11, с.42]. При этом Г.П. Щедровицкий [8, с.97] считает, что уже на рубеже XI-XII вВ. рефлексия из «соотношения человека с внешним миром» (культура, мышление и деятельность) перешла в план «сознания, психики и души», т.е. формируется предположение, что человек обладает сознанием самого себя и своей деятельности, или, иначе, встает вопрос о рефлексирующей деятельности сознания, но сколь сформированное выражение этой идеи мы находим только в трудах Н. Кузанского, а уже емкое и оформленное ее выражение в классических работах И. Канта, И.Г. Фихте, Г. Гегеля, позже - Э. Гуссерля, М. Хайдеггера, М.К. Мамардашвили, А. Камю и др.

Но сколь бы мы не рассуждали о «предощущениях» и «пред- рассуждениях» о рефлексии, первым это понятие как «способность сосредоточиться на содержании своих мыслей, абстрагироваться от внешнего, телесного» [15, с.178] ввел Р. Декарт, а развил идею о двух источниках знаний (объекты внешнего мира и деятельность нашего ума) Дж. Локк [5], понимавший под рефлексией особое внутреннее чувство человека как способность преобразовать в мысль чувственные впечатления о мире с одной стороны, и процесс самоисследования человека посредством сознания с другой.

Не вдаваясь особо в глубину философского понимания рефлексии в трансцедентальной традиции (Р. Декарт, Дж. Локк, Л. Лейбниц, И. Кант, И.Г. Фихте, Г. Гегель, Э. Гуссерль и т.д.), где рефлексия непосредственно связывается с сознанием и считается явлением, надстоящим по отношению к чувственному восприятию мира и этим «воцарившей» идею рефлексии в философии, особое место рефлексирующего сознания в психологии больше определило, на наш взгляд, развитие идеи рефлексии в герменевтико-экзистенциальной традиции (М. Хайдеггер, Ж.-П. Сартр, А. Камю, М. Бубур, М.М. Бахтин и др.), «вплетающей» рефлексию в коммуникативные акты, обусловленную ими и их же обуславливающую, определяющую взаимное понимание и переплетение оценок и самооценок участников взаимодействия [1].

И здесь в контексте нашего научного интереса определения места рефлексии в конструкте зрелости личности мы остановимся на некоторых общих моментах, а именно контекстности рефлексии как конструирующей сознание функции, на понимания роли социального в становлении рефлексии и на мести и роли Другого в становлении рефлексии, а также на отдельных качественных характеристиках специфики проявлений рефлексии, замеченных как рядом авторов, так и нами самими.

Чуть ли не центральными вопросами философии, а до нее теософии, выступает соотношение души и тела с одной стороны, и, с другой стороны вопроса наличия души у животных. И если по первому вопросу в научных спорах ломались копья многими маститыми авторами, перечисление имен которых займет страницы, то соотношение по второму вопросу легче всего свести к двум именам: Р. Декарт отказывал всем животным в наличии души (и трактовал поведение животных фактически механистично, как «живых автоматов»), в то время как его оппонент Г.В. Лейбниц приписывал ее наличие всем природным телам (даже традиционно считаемым неодушевленными), но здесь же Г.В. Лейбниц в корне отличал «животную душу» как неспособную думать о самой себе, от души человека, и в этом контексте слово «рефлексия» понимается Г.В. Лейбницем в контексте «отражения» как способности человека «думать о самих себе» или «осознавать себя», «знать о себе» $[6$, с.37].

Современный отечественный философ и лингвист В.П. Руднев считает необходимым разделять мир, окружающий человека, от его реальности, понимая в первую очередь под последней процесс динамического субъектного отражения тех явлений, которые, прежде всего, непосредственно связаны с внутренним миром челове- 
ка, его смыслами, текущими целями и задачами, но также с его текущим настроением, самочувствием и т.д.: «<...> для каждого, кто идет по оживленной улице, эта улица будет разной, в зависимости от настроения, мироощущения и других субъективных факторов. Кто-то оказался на ней впервые и с интересом разглядывает здания и людей; другой живет на этой улице и вышел в соседний магазин за покупками - в таком случае он поздоровается с соседями и пойдет по известному ему направлению; третий спешит после тяжелого трудового дня и все вокруг кажется ему мрачным и раздражающим, и так далее. В этой картине реальности останется неизменным лишь название улицы, и в этом проявляется семиотический характер реальности» [13, с.165]. Таким образом, согласно В.П. Рудневу, наше восприятие реальности, вопервых, всегда субъектно (как минимум, эмоциональнопристрастно), во-вторых, знаково, т.е. преломлено через посредство знака (вербально обозначенного или написанного слова как означающего, числа как другого проявления знака, наконец, «значимого для нас», т.е. именно вписанного в канву личностно значимого, т.е. соотнесенного с нашими переживаниями, интимно-личностного). Но при всей «избыточности речи» в лучшем понимании явления (например, известно, что русский язык полисемантичен и способен отражать многие нюансы и оттенки), верно и лакановское «извечное скольжение по означающим» как причина постоянного человеческого невроза («отслоенности» означающих от означаемого, что нередко вызывает разночтение пониманий), но также верно и другое, высказанное одним из малоизвестных поэтов 80-х гг. XX в.: «<...> означишь словом, смогут все украсть», где речь идет о подстройке сознания к означающему, что также ведет к искажению смысла. Иначе говоря, в ситуации с «эмоциональной» улицей В.П. Руднева непосредственно от улицы «остается» лишь ее название (знак или символ), а все остальное всегда несет на себе оттенок того или иного нашего переживания, что вызывает к нас вопросы.

Сделаем собственное отступление: наше говорение иногда оказывается гораздо меньше смысла проговариваемого. Так, выражение: «вампира можно убить только осиновым колом или серебряной пулей» восходит к зависти Иуды Искариота к всенародному признанию Христа как пророка (влияние на людей, из которого, если следовать замыслу Иуды, можно получать выгоду, буквально «пить кровь») и к тому, что Иуда продал Христа за 30 тетрадрахм (серебряников, т.е. 30 монет серебра) и после - повесился на осине. В самом говорении «можно убить осиновым колом или серебряной пулей» сокрыто значение, слишком далекое от лица действия - вампира, и здесь семантический код отсылает нас к совершенно иному событию, не знаемому или не подразумеваемому нами в контексте повествования о вампире. Но знание истории Иуды и того, откуда возникла вообще идея возможности применимости средств для убийства вампира вводит нас в совершенно иное смысловое поле, изна- чально никак не подразумеваемое. Иначе говоря, с нашей точки зрения именно смысловая нагрузка задает «тон» и семантическому полю явления, и связанных с ним так или иначе эмоционально обозначенных ассоциаций. И в этом контексте общее самоощущение жителей Малого Арбата или Монмартра будет, скорее всего, отличаться от самоощущения жителей улицы имени Ященко, хотя и эти переживания имеют под собой совершенно иную почву, нежели вопрос о «простуженной» улице. При этом можно согласиться с эмоциональным восприятием улицы с В.П. Рудневым в том аспекте, что оно отлично для человека, прожевавшего на ней в особняке, а затем посетившего ее в качестве бомжа, или посетившего ее ранее туристом и живущего на ней потом гастарбайтером, жившем на ней до войны и вернувшимся с нее в руины, но это, как говорится, другая история, и в ней место не столько рефлексии, сколько следам памяти.

И здесь мы также обращаем внимание на специфическую философскую систему В.П. Руднева, считающего, что и в восприятии внешнего решающее значение имеет наше внутреннее, откуда, в целом и следует понимание того нарратива, которым может сопровождаться описание улицы. Причем чем более этот нарратив эмоционален, тем более он отражает наше внутреннее. Но ведь чаще всего следуя по улице в различных своих состояниях, мы делаем «скидку» именно на наши состояния, и улица для нас может быть «мокрой» в дождь или «промозглой» во время ветра, но не «простуженной», «усталой» или «восторженной», т.к. именно благодаря нашей рефлексии, здесь, как и во многих случаях «работающей» на пред-сознательном уровне (при желании процесс такого осознавания может быть легко восстановлен), мы «отсекаем» наше «внутреннее» от внешнего; и здесь отчасти можно согласиться с В.П. Рудневым или его поправить: «внешнее» - это «принадлежащее миру», но наше «внутреннее» и наше восприятие этого мира, на которое действует одновременно и наше внутреннее состояние (в том числе и, порождая метафоры, например, «грустной улицы»), это и есть наша (психическая) реальность, и эта реальность не может быть иной, кроме как нашей (человеческой) психической (т.е. отраженной, но отраженной специфически, в силу целого (большого) ряда особенностей), но и здесь проявление сути нашего психологического здоровья имеет место именно в «отсечении» (рефлексировании) внутреннего от внешнего.

В контексте нашего рассуждения в ракурсе приближения разговора о роли и месте рефлексии в построении сознания и о связи рефлексии со зрелостью личности (или ее своеобразном отстоянии от эмоционального, или, точнее, субъектного), сделаем неточную ссылку на Э. Гуссерля, считавшего, что наше сознание, это всегда «сознание о чем-либо», и ссылку на М. Мерло-Понти, развившего эту идею и считавшего, в отличие от Э. Гуссерля не «я мыслю», но «я могу», и этим подчеркивающего интенциональность тела как способ активного суще- 
ствования в мире («чистое восприятие» невозможно, и, как следствие, всегда есть только слитное чувствование «меня и мира» или «меня в мире», что без тела невозможно, и условия восприятия мира заданы человеку только его телом и восприятие и познание мира для человека невозможны вне активности человека, т.е. без его телесной экспрессивности [9, с.131].

Однако и «сознание о чем-либо», или, перефразируя, «мысль о чем-либо», и активность «присутствия в мире», невозможная вне телесности - есть свойство всего живого, или, по крайней мере, всего высоко развитого живого: владельцы домашних собак знают, как легко возбудить животное предложением не просто прогулки, а именно прогулки в любимое собакой место. Таким образом, собака в той или иной мере способна к фантазированию, или, по крайней мере, к ментальной репродукции тех или иных образов, и это также хорошо видно при наблюдении реакций собаки на ее сновидения. Однако со всей очевидностью, понятно, что речь идет о факторах непроизвольности/произвольности психической регуляции, и если даже сдерживаемое и контролируемое самой собакой поведение в отсутствие человека можно считать в определенном смысле самодетерминированным, его все же нельзя считать свободным, что в корне отличает человеческое поведение. Иначе говоря, в данном случае самоограничительное поведение животного прежде всего условно-рефлекторно, но также оно может далее и иметь производную «так поступать нехорошо и я могу быть наказана», но это не свобода детерминации своего поведения, а определенная степень предвидения его последствий. Так же шимпанзе может использовать палку, чтобы достать корм, но специально искать палку, и, тем более, «в плане» делать из него орудие, чтобы достать корм, шимпанзе оказывается не в состоянии; т.е. отличительное поведение человека в этом случае - в отдаленном планировании и прогнозировании действия и его последствий. Таким образом, трудовой деятельностью не могут управлять ни инстинкт, ни рефлекс, и здесь нет готовых механизмов поведения, и, хотя человеку и свойственно часто в начале делать, а потом понимать суть делаемого, этот процесс он проходит быстрее, чем животное, в основном посредством более быстрого осмысления, и, прежде всего, трудовых операций, и это уже есть простейшие проявления рефлексии.

Специфическим явлением человеческого сознания является способность узнавать себя в зеркале, которая, согласно Ж. Лакану [4], впервые проявляет себя примерно в полугодовалом возрасте, еще до установления у ребенка хорошей координации, и эта стадия, по Ж. Лакану, является фактически первой образующей функцией Я. Как известно, животные не узнают себя в зеркале (считается, что это доступно только высшим приматам), и, видящая свое отражение кошка, видит в зеркале другую кошку. Узнавание себя в зеркале представляет из себя привычную самоидентификацию как проявление понимания отличия себя от других, однако при определенной схожести с ними. И здесь проявляется одно из важнейших функций сознания - видеть в другом себя и видеть в себе другого [6, с.37], и все это реализует себя на идеальном (воображаемом) уровне, что отличает идеальное отражение от физического: непосредственно увидеть себя со стороны невозможно, и наше «видение» себя принимает форму двойного (свернутого) опосредования, причем всегда социального: спрашивая подругу, как выглядит мое платье, девушка как бы смотрит на себя со стороны, но дальше принимает ее мнение как бы за свое (и, при этом, чаще всего, не будучи наивной, делает «сноски» на мнение этой «подруги»: «Вам нравятся сапоги? Нет?! Значит, надо брать» (примерная цитата из «Служебного романа»), что уже является рефлексирующей работой сознания [6, с.37]. И эта способность увидеть себя глазами другого, со стороны, качественно отличается от непосредственно детского восприятия мира как чувственной картинки, и можно ожидать, что примерно схожее восприятие мира имеют высокоорганизованные животные (но их мировосприятие еще и сильно обусловлено необходимостью удовлетворения биологических потребностей).

Хотелось бы обратить внимание на еще одну особенность сознания: сознание - это «общее качество, присущее психологическим процессам» (по Л.С. Выготскому), но о сознании мы говорим только применительно к человеку, и оно сообщает новое, совершенно иное качество всем психическим процессам, которые, в общем, присущи и высшим млекопитающим (память, эмоции, рассудочная деятельность (в чем-то мышление), но отличие сознания в том, что оно рождается лишь при общении с себе подобными [6] (и здесь мы добавим, что только благодаря рефлексии рождается самосознание (само-о-сознание) как способность отделения себя от себе подобных, но грани сознание/самосознание всегда нечеткие). При этом сознание является «над-процессом»: здесь есть и мышление, и память, и эмоционально-чувственное отражение, и необходим определенный уровень интеллекта, но этого всего недостаточно, сознание надындивидуально и его образование невозможно вне человеческого (социального) взаимодействия. И, кроме того, мы оказываемся неспособны найти «место» для сознания ни в мозге человека, ни, тем более, в его теле (т.е. - определить «мозговой субстрат сознания»).

При этом и в человеческом общении исключительную важность имеет надиндивидуальность его мотивов. Поясняя это, обратим внимание, что в своей обзорной статье Т.А. Росийчук [10] показывает, что у «не-человеческих обезьян» (как сейчас называют высших приматов, отделяя их тем самым от непосредственных предков человека, впоследствии ведущих к линиям Homo Erectus и Homo Habilis) отмечается и высоко развитое воображение (по крайней мере высшие приматы могут «носиться» с деревянным чурбаками, изображая нянченье, однако 
здесь мы не знаем, насколько тесна проекция родительских ожидания такой обезьяньей «мамки» на этот предмет, но мы достаточно хорошо понимаем похожую ролевую игру 3-4-х летней девочки, где эта игра, конечно же, еще слишком далека от репертуара родительского поведения взрослого, но факт остается фактом, такое «нянченье» у шимпанзе прямо отражает наличие у нее достаточно развитого воображения), и предметной деятельности, и оперирования довербальными понятиями (уровень «наших» смысловых примитивов), и умение участвовать в разделенном опыте, и даже способности понимать намерения других, но перспективы коммуникации приматов ограничиваются лишь функцией требований для себя, и в отличие от них человек способен а) разделять общие с другими коммуникативные намерения, б) организовать совместный опыт и в) продуцировать совместное (социальное) внимание (по М. Томаселло). При этом высшим приматам, как и первобытному человеку, доступна символизация реальности на уровне жеста и звука (феномен «говорящих обезьян», фактически отражающих речь ребенка 2-3- летнего возраста с возможностью эффекта опережающего понимания). Но человеку свойственно осмысление жестового языка с прохождением его через воображаемое с произвольным управлением воображаемыми образами (в более раннем филогенезе эти образы «текут» неподконтрольно и без связи с соответствующим контекстом, почти как у нас в сновидении), и дальнейшее освоение человеком речью позволяет управлять этими образами уже в их отрыве от внешнего контекста. И здесь, на наш взгляд, уже примитивная рефлексия говорения создает исключительные условия для контроля образов как «слепка» реальности (и этот «слепок» никогда ей не тождественен), и как следствие является своего рода демиургом сознания, и здесь совершенно справедливо высказывание (Г.В.Ф. Гегеля, упрощенно) о том, что «я знаю о том, что я знаю (этот предмет), и я знаю, что ты этого (предмета) не знаешь», что уже определенным образом и характеризует, и качественно определяет самосознание.

При всем понимании того, что рефлексия является очень сложным явлением, и принятии того, что она, скорее всего, никогда не будет однозначно не только концептуально, но и терминологически определена (связана с самонаблюдением, интроспекцией, ретроспекцией, самосознанием (словари В.П. Зинченко и Б.Г. Мещерякова, С.Ю. Головаря и В.Б. Шапарь, Г.М. Коджаспирова, Л.В. Мардахаева, Е.С. Рапацевич и др.) [16], пониманий рефлексии, направлений ее исследований достаточно много, и здесь особое внимание, на наш взгляд, представляют идеи так называемого субстратного подхода (представители - А.В. Карпов [3], А.С. Шаров [14], Т.Э. Сизикова [12] и др.), ориентированного на выделение онтологии рефлексии и элементарных ее единиц, а также систематизацию данных, полученных в других подходах, как например, в атрибутивном, структурном, функциональном.
В связи с темой нашего исследования («месте» и «роли» рефлексии в аспектах здоровья и зрелости личности) нам бы хотелось, используя мнения ряда авторов, а также опираясь на собственные наблюдения и выводы, продолжить вектор этого (субстратного) подхода к рефлексии, и нам представляется, что наши собственные воззрения ближе укладываются именно в его рамки.

Как известно, особенностью рефлексирующего сознания является как бы вынесение наблюдающего сознания за скобки восприятия внешнего мира: человек может, не отключаясь от него, быть погруженным в свои рассуждения, собственный внутренний мир (и весьма с разной глубиной и интенсивностью), и здесь в тезисе Э. Гуссерля о всегдашнем сознании как сознании о чемлибо необходимо учитывать, что «думание» о своем внутреннем - это и может быть рефлексия, совершаемая в условиях чувственного восприятия внешнего мира, но почти вне фиксации этого чувственного восприятия, т.е. с периферийным участием внимания и с сохранением необходимого автоматизма действия, но при сосредоточении на внутреннем. И здесь хотелось бы сделать одно важное замечание, произведенное В.А. Миловидовым [7] при анализе цитат из стихотворений Б. Пастернака (в частности, сюжета из «Гамлета» «Гул затих, я вышел на подмостки...»), отражающих размышления о выборе пути. В.А. Миловидов обращает внимание на феномен «мерцания» смысла (термин Б.В. Томашевского) («Содержание лишь мерцает сквозь выражение, а выражение лишь намекает на содержание» - фраза Ю.М. Лотмана [7, с.223]. Нам представляется, что фактически вся работа рефлексии реализует себя в качестве «мерцания»: рефлексия сама по себе есть отстранение, но это отстранение не есть полное отзеркаливание, но некоторая метафоризация или взаимоналожение (эта идея также заимствована нами у В.А. Миловидова) других, хотя бы косвенно связанных с анализируемым явлений, затем их многоуровневая «фильтрация», до тех пор, пока мы не придем к удовлетворяющей нас «истине».

На наш взгляд для рефлексирующего сознания была бы наиболее удобна метафора создающего свою Галатею Пигмалиона, но, часто, с растянутым во времени процессом «ваяния» (хотя, согласно мифу, Галатея сотворена из слоновой кости), что также зачастую обусловлено недостаточностью «средств». Поясним и метафору, и ход собственных рассуждений (далее мы имеем нескромность предложить некоторые собственные максимы о природе рефлексии).

Говоря несколько утрированно, рефлексия - это процесс, ориентированный на понимание ситуации или явления (в профанных содержаниях - себя, своего состояния, иногда своего поведения, детерминированного нашим бессознательным и в этой связи приносящего нам удивление, поведения других людей (мотивов, целей и т.д.) близких нам и с нами работающих, а также 
более глубоких явлений, как например, педагогического процесса, дискурса, семинара и т.д.). Но совершенно понятно, что такая рефлексия опирается на систему наших знаний (а она - на парадигму и нашего мышления, и существующие в обществе научные парадигмы, или выборочно предпочитаемые нами), наш опыт и умение его использовать. И эти знания, и, особенно, их использование, и выборочны, и несистемны. Именно это мы прежде всего и понимаем в качестве «мерцания» рефлексии. И в этой связи мы бы хотели высказать свои дополнения в отношении основных свойств мышления - его содержательности и предметности. В вопрошающей фразе «где находится поликлиника МВД?» объектом является «поликлиника МВД», а вся фраза отражает содержание мысли. Но в целом вся эта фраза как смысловое выражение - это семантический код говорения, отражающий смысл запроса. Ответ «на улице Московской, 77» отсылает спрашивающего к новому семантическому коду «а где улица Московская?», если он не знает города. Зная же, где расположена улица Московская, житель или приезжий Ростова спросит: «а это блице к Центральному рынку, или же к Часовому заводу?», и это уже позиционирует в мышлении поликлинику МВД, ранее существующую для него как объект, к месту. Таким образом, наше мышление, с нашей точки зрения, обусловлено не столько объектом (а все справочные издания главными свойствами мышления выделяют его предметность, и, через это свойство - его содержательность), сколько именно местом (топосом). При этом топический характер мышления, по сути, обусловленный доминированием у нас зрительной системы, и, как следствие - фактически постоянным присутствием в психическом аппарате ментальных образов, всегда опирающихся на мнестические следы, и далее на событийное содержание, и уже после них на их эмоциональную оценку, которая у нас меняется (и в этой связи образуются покрывающие воспоминания), часто играет с нами определенные «шутки», как например, поиск «места» души (а после того, как в первой половине XX столетия ее место было «отдано» сознанию) в теле, в итоге не окончившийся ничем, т.к., как это уже было показано, сознание - это над-процесс, над-явление и над-состояние, причем более чем сингулярное, как любовь, здоровье и пр., т.е. глубоко индивидуальное для переживания каждого из нас и отличное от других, и тем более, оно гораздо больше синергии проявлений мышления, памяти и т.д., и уже в этой связи не имеющее «места» в теле и даже в мозге.

И в этой связи если в нашем понимании мысль - это прежде всего место, т.е. нечто статичное, объектно-привязанное, то рефлексия - это, в некотором роде, процесс создания Пигмалионом Галатеи, процесс, лишь в редких случаях приходящий к завершению, но по своему большинству всегда производимый «при недостатке глины», а потому достраиваемый, но и в значительной степени эмоционально пристрастный уже в силу интимной связанности рефлексии с переоценкой участвующей в ней нашей «научности». И в своей совокупности участвующих процессов и переживаний (помимо знаний и опыта, как говорилось выше, это также воображение, часто эмоционально «захвачиваемое») работа рефлексии максимально реализует себя в создании нашего индивидуального мифа мировосприятия мифа внутренней реальности.

Процесс рефлексирования, будучи в разной степени энтропийным, в своем накале может оказаться очень затратным и при малой (с точки зрения рефлексирующего) своей эффективности может вести к разочарованию и в отдельных случаях к фрустрации, если не к депрессии, но в этой связи состояние пребывания человека в рефлексии и итоги этого процесса могут иметь и другие следствия.

Рефлексия имеет очень специфичную временную организацию: по сути опираясь на прошлые знания, прошлый опыт и анализируя уже произошедшее, рефлексия в своем выводе ориентирована на будущее и из будущего по-своему исходит в «нуждаемости» и применимости (запросе) своих выводов, но производится она максимально в здесь-и-теперь настоящем, этим самым делая его (настоящее) в наибольшей степени рельефным. При этом она производится в некоторой «теневой», нечеткой сфере сознания, но производимую ею эмоциональную захваченность в работе когнитивной функции можно сравнить с предощущением инсайта, и такая работа мышления и сознания в целом вкупе с некоторой такой субъективно переживаемой эмоциональной возвышенностью часто переживается как некое подобие выделенного А. Маслоу экстатического переживания как высшей ценности.

Опирающийся на рефлексию самоконтроль исходит из «думания наперед» в рефлексии, и такое «думание наперед», пожалуй, является одним из первых и наиболее важных проявлений рефлексии, в своей основе доступных уже малым детям, а также высоко организованным животным, как, например, собакам, если собака живет непосредственно с человеком и им воспитывается. Не желающая обидеть хозяина собака в его отсутствие не шкодит, что, конечно же, требует организации такого навыка. Но чем собака импульсивнее, т.е. чем выше ее возбудимость и ниже самоконтроль, тем легче собака срывается в своем поведении, невзирая на ожидаемое наказание, и, простите, шкодит. В имеющем место трагическом случае выпавшего из окна второго этажа пятилетнего ребенка роковую роль сыграло наличие под окнами играющих сверстников. Пятилетний ребенок в достаточной мере осведомлен о возможности и последствиях выпасть из окна, т.е. последствия для него в уже доступной для него степени очевидны. Однако именно новый более сильный очаг эмоционального возбуждения сводит рефлексию поступка на нет (и этим отрицается будущее как возможность реализовать себя, не 
погибнув, но с высокой вероятностью став инвалидом, т.е. отрицается опыт протяженности своей жизни из прошлого в будущее, но полностью акцентируется здесь-итеперь импульсивная поведенческая реакция). Таким образом, рефлексия в норме - это постоянная активность по самоконтролю, которая, собственно, и создает наше здесь-и-теперь переживание внутренней реальности, согласующейся со внешней; или иначе, это переживание происходит на «стыке» нашего внутреннего с внешним, что также переживается большей частью как внутреннее, но в отличие от преимущественно чувственно-контактного переживания мира ребенком, рефлексия прежде всего базируется на когнитивных характеристиках оценки внутреннего и внешнего.

Из этого может следовать вывод о динамике формирования рефлексии в онтогенезе (контроль над поступком/дееспособность - контроль над эмоциями/психическая и психологическая зрелость - контроль над способами мышления как возможностью организации планомерности поведения, что также учитывает и зрелость рефлексии в контроле над эмоциями).

«Мерцающий» характер рефлексии несколько «приближает» ее к непроизвольным психическим процессам (что эмоционально возбуждает, то и привлекает внимание, но это внимание может достаточно быстро угасать). Однако истинно работающая рефлексия как процесс постоянной включенности в жизнь, осмысления и смыслопостроения жизни, требует акта воли с необходимостью поиска решений для непонятного, часто отложенных решений, и, при этом отложенных на неопределенный срок, пока не поступит новая информация по предмету рефлексивного анализа, с выбором и анализом мнений, реализаций собственных решений для со-мнений (бинарных или близких к ним оппозиций) и т.д.

Рефлексия так же может обладать мотивирующим характером (сдвиг мотива познания на собственную цель, т.е. обретение в объекте рефлексии позиции объекта научного познания), но изначально рефлексия, скорее всего, не имеет своей собственной цели, но всегда имеет предмет и интерес к нему, либо обусловленную предметом рефлексии фрустрацию.

Хочется дополнительно подчеркнуть особенности рефлексии как обостренного здесь-и-сейчас переживания. Ф. Ницше указывал на то, что жизнь начинается из будущего. Близка к этому и мысль М. Хайдеггера, согласно которой исходя из планов на будущее мы меняем настоящее, но это также и влияет на наше восприятие прошлого, оценку которого мы не просто изменяем, но подвергаются изменению и наши воспоминания прошлого. Но именно рефлексия как процесс постоянного смыслопостроения укрепляет нас в бытие, в здесь-исейчас, как наиболее остро переживает свое бытие ребенок посредством своего чувственного ответа миру (например, в остроте переживания солнечного луча на стене комнаты), так и рефлексия укрепляет взрослого в его здесь-и-теперь присутствии. Иначе говоря, как для ребенка его острое чувственное переживание мира отвечает его аутентичности, так и рефлексия формирует чувство аутентичности у взрослого.

Если способность контроля своего поведения отвечает вопросу вменяемости человека, а способность контроля над эмоциями критерий психологической и психической саногенности, то контроль над мыслями следует прямо связывать с нравственными качествами человека, т.к. использование человеком своего интеллекта вне проживания им нравственного поля самосознания открывает ему перспективы эгоистической вседозволенности, любых объяснений несоразмеримого галоцентризма, любого «убийства бога» или создания любых мифов с целью самовозвеличения (хотя на деле все и гораздо сложнее, и несколько проще, например, хочет ли человек вообще думать о том, что его развязная эмоциональность приносит дискомфорт окружающим?).

Почему мы так акцентировали внимание на связи рефлексии со здесь-и-теперь переживанием?

Аристотель считал, что «обращенность ума на себя избыточна в устоявшемся укладе жизни» [11, с.42], и мы уже говорили о том, что древние греки ориентировали себя на действие, а не на размышление и рассуждение, хотя ораторство было развито и у них, и у римлян. Но использовалось оно в основном в спорах, и, особенно, в суде, чтобы склонить судей в ту или иную сторону. Для рефлексии нужна остановка (свободное время) и место (тело), и в этой связи интересна парадоксальная идея о «зарождении» рефлексии в актах признанных для данного общества праздниках-мистериях (а эти праздники были индивидуальными, в частности, для каждого греческого полиса-государства) с осуществляемыми во время этих празднеств жертвоприношениями, «Ибо жертвоприношения по сути исполняли ту же роль обретения надежных оснований порядка жизни, ее безопасности и осмысленности, которую позже стала выполнять рефлексия» $[11$, с.46]. Но такие праздники-мистерии всегда сопровождались и невероятным (но всегда контролируемым по своей временной ограниченности) разгулом плоти (пиршества, алкогольные возлияния, секс без разбора, агрессия). Связь идеи оргий с рефлексией на первый взгляд может выглядеть и вздорной, но в ней есть два важных, на наш взгляд, момента. Первое, это жертвоприношения как идея задабривания богов, т.е. символ жертвы прежде всего следует понимать в гарантии привычного чередования жизни: задабривание богов может дать хоть какую-то гарантию реализации привычного круговорота жизни («будет день, будет и пища», т.е. урожай, и может даже отсутствие болезней). Второе - это «возвращение в тело». Как известно, у нас может быть привычный секс с женой, может быть секс с любовни- 
цей, может быть секс по принуждению (изнасилование), могут быть гомосексуальные сексуальные отношения. Отбрасывая социальные аспекты перечисленных вариантов отношений (супружеский долг, адюльтер, абьюз, аберрация), секс с физиологической точки зрения остается сексом - коитусом. Но с психологической точки зрения это совершенно разные явления, оставляющие совершенно разное впечатление. Точно также происходит и с различными другими явлениями: работая на хозяина, мы испытываем совершенно иные эмоции, чем выполняя творческую самомотивированную работу, и во всех этих переживаниях и наши временные (хронологические), и наши пространственные (топические, и, более того, субъектно-телесные) представления оказываются различными. Другой хорошо известный многим пример, это «пятница-развратница», когда отдельные индивиды в пятничный вечер не без применения алкоголя, а иногда и с «участием» секса (часто с сослужив(и)цами) «сбрасывают» с себя весь гнет рутинных переживаний недели: встал, умылся, позавтракал, сел в автобус, отвел ребенка в школу, пришел на работу, отработал, пришел домой, покормил ребенка, проверил уроки, получил отказ «у меня голова болит», поспал, проснулся, умылся. Мы не задумываемся о том, что такая монотония встраивает нас в один и тот же жизненный ритм, повторимость которого гарантирует нам надежду, что завтра мы так же проснемся, умоемся, позавтракаем, и что, в лучшем случае, мы не умрем во сне. Таким образом, такая повторимость событий с нашим обсессивным в них участием это защита от наших страхов перед неопределенностью будущего. Но ведя ребенка в школу, мы думаем о своем, сев в автобус, утыкаемся в гаджет и т.д. Таким образом, мы в этих случаях присутствуем не здесь, и по большей части не полностью в «своем теле»: мы существуем преимущественно в фантазийном мире, который определяется как «не здесь» и «не сейчас». Часто мы так или иначе думаем о том, что нам необходимо сделать (временная перспектива - будущее, реализация которого вероятностна), к нам приходят воспоминания (прошлое), которые мы еще менее способны контролировать (менять). Но вот, наконец, пятница! Можно выпить, и почувствовать, как разливается по телу приятное тепло, затуманивается мозг и многое из негативного выходит за скобки, и здесь уже «вагонные споры» или кухонный треп - это уже почти рефлексия. Мы, наконец то, остановили время и так глубоко почувствовали свое тело: наконец-то, вот оно, и здесь, и теперь. А если еще секс с сослуживицей?! Да это же какой полет воображения?! И здесь уж точно слилось и воображаемое, и реальное, и знаковое (это в понедельник мы не будем знать, что с такими «знаками» делать). И даже негативный опыт регулярного похмелья не в счет: боль в голове, нытье в печени, несварение желудка - все это то, что лишний раз нас фиксирует на теле, замечательно отвлекая от пространства («нужно же убраться в квартире!», но я не могу!») и времени. Вот оно заветное «здесь-и-теперь».
Фактически через все работы В.Д. Руднева, посвященные характерам, а таких работ достаточно много (и он делает очень глубокие психоаналитические обзоры целого ряда характеров), проходит подробный анализ наиболее представленных в «человеческой выборке» характеров группы обсессивно-компульсивных (это объединенная признанная многими маститыми психоаналитиками (Н. Мак-Вильямс, О. Кернберг и др.) группа по специфике психологических защит, общности объектных отношений, «места» характера «среди» стадий психосексуального развития и пр., но характеров, также несколько отличающихся между собой. Так если для компульсивного характера более свойственно почти всегда навязчивая деятельность (редуцируя, можно сказать, что если обладатель такого характера не начинает свой день с привычной работы, то испытывает тревожность), то для обсессивного - это постоянное обдумывание. И тот, и другой характер, естественно, имеют глубокие исторические вполне объяснимые корни, что особенно объяснимо в случае компульсивного характера: выполняя работу, ты не только оказываешься отвлечен от своих страхов и опасений за будущее, но также и в отношении иных переживаний, но тем самым своей работой ты гарантируешь себе в той или иной мере свое обеспеченное будущее. Обсессивный характер чаще объясняют стремлением человека упорядочить мир вокруг себя, или, точнее, упорядочить собственные здания о мире. В этой связи приводятся типичные представители компульсивного типа характеров почти все «трудовые» профессии, а в несколько «интеллигентном» «ракурсе» - бухгалтеры, хозяйственники и т.д., и обсессивного - ученые, нотариусы, адвокаты, психологи и пр. И здесь, если основной вектор реализации компульсивного поведенческого повторяемого акта можно свести к снижению страха перед будущим методом повторения процесса труда, то навязчивое повторение через поиск новых интеллектуальных граней анализируемого для обсессивного характера не всегда объясним, т.к. его «омысливание» далеко не всегда касается вещей и явлений, которые «помогут жить» (проще говоря, будут гарантировано оплачены, т.е. позволят иметь столь «сытое» будущее). Обсессивный человек продолжает «обсессию» своей мысли почти постоянно.

Другим важным наблюдением В.П. Руднева является то, что он считает самым рефлексирующим типом психастенический характер, и здесь В.П. Руднев вслед за М.Е. Бурно, сочетает его с мазохистской и меланхолической (т.е. депрессивной) конституциями в психоаналитической характерологии. Однако также необходимо иметь ввиду и высокую обсессивность такого характера, и, пожалуй, чуть ли не самую слабую его социальную адаптивность. Иначе говоря, психастеник претерпел чуть ли не все неудачи на этапном пути своего стадийного психосексуального развития (в аспектах психодинамического подхода), какие было возможно. 
В чем же тогда особенность обсессивного характера, прежде всего состоящая в столь свойственном ему навязчивом обдумывании?

На наш взгляд, если компульсивный человек именно навязчивым деланием (в обиходе это трудоголизм) спасает тем самым себя от тревоги за будущее, то обсессивный человек посредством «магии своих мыслей» (эта идея развивается уже 3. Фрейдом) пытается оградить себя и от страхов за будущее, но, что мы особо подчеркиваем, он более пытается оградить себя от собственного соскальзывания в столь приятное для всех невротических характеров прошлое (а специфика нашей памяти больше помнить «хорошее» прошлое всем известна), от своей оральности.

Таким образом, как следствие, особенно часто встречающийся компульсивный тип характера «живет» преимущественно в психологическом будущем, а обсессивный, как бы он его не старался избегать и от него защищаться, в психологическом прошлом.

Еще одно важное замечание В.П. Руднева, касающееся психастенического характера, это слабая связь этого характера с телесностью, и то, что такой человек всегда пребывает и не полностью в настоящем теле, и не до конца в настоящем времени, а всегда где-то.

Мы считаем, что то же самое, но в несколько меньшей выраженности, можно говорить и об компульсивном, но еще более чем для компульсивного, это свойственно обсессивному характеру. Хорошая связь с телом и относительно хорошая связь со временем (субъективным пребыванием во всех трех временных перспективах) боле свойственна сангвиническому характеру (именно характеру), являющемуся синтонным проявлением циклоидного характера.

Из всего сказанного мы делаем заключение, что и рефлексия, на примере являющая себя болезненной зарефлексированностью психастеника, очень различна для представителей разных типов характеров (которые, как известно, «чистыми» не бывают), и это также следует принимать во внимание при рассмотрения включенности рефлексии в структуру зрелой личности. Но и «пребывание в теле» как субъективное ощущение может быть разным у представителей разных характеров, или иначе, каждый из нас, будучи в определенном смысле заложником своего характера, в каждый данный момент времени в определенном смысле не в полном объеме находится в здесь-и-сейчас для разных аспектов своей телесности.

И, наконец, еще одна история, поведанная матерью двоих детей, владелицей достаточно крупной породистой собаки, и, в целом, очень внимательным человеком. Выведя собаку, проживающую в квартире, на прогулку, эта женщина была свидетельницей следующей истории. По улице очень медленно и поминутно останавливаясь, и уделяя друг другу внимание, дефилирует пара: женщина лет 65-ти (бабушка) и молодой человек лет 5-ти (внучик), восседающий на двухколесном велосипедике, задние колеса которого опираются на страхующую малую колесную пару (почти советский сюжет). Будучи вынужденной обогнать эту пару, владелица собаки застает сцену: бабушка, почти все время придерживающая велосипед внука за сиденье сзади (все известно - ребенок только учится ездить), лезет рукой в свою корзинку, сопровождая движение словами: «Опять пить?! Да ты только что пил! Ты не делай вот этих звуков, у тебя от них рот и пересыхает». При этих словах мальчик обеими ножками почти изо всех сил так лупит по педалям велосипеда, и при этом его движения никоим образом не напоминают попытку их вращения, что это больше похоже на истерическую фугу. Ну, ситуация как ситуация. Хозяйка собаки продолжает свое движение, ибо физиология животного такова, что ему необходимо, некоторым образом, размяться, чтобы, простите, совершить свое естество. Значительно опередив эту пару, женщина с собакой возвращается назад, но ситуация такова, что на улице примерно на ближайшие 7-8 метров всем будет разойтись сложно, и владелица собаки, ее придерживая, берет в сторону. В это время она слышит диалог подходящих к ней мальчика и бабушки. Доступным ему языком ребенок замечает: «Собачка прошла вперед, а теперь уже возвращается». На что бабушка отвечает: «Ну, ты же медленно едешь, а собачка быстро ходит, вот она уже и возвращается». При этом выражение лица ребенка - абсолютно кукольное, которое любят изображать режиссеры, когда хотят показать в кино, что ребенок лукавит, а в подтексте фразы бабушки легко прочесть весь объем сдерживаемого ею раздражение всей прогулкой с ребенком.

К чему такое длинное повествование? Рефлексия это, фактически двухуровневость или двусложность мышления (не путать с раздвоением личности). Бабушка совершенно не хочет замечать (по крайней мере во внешнем плане), что ребенок всеми своими силами пытается ею манипулировать, и его разговор о собаке - это уже рассогласование планов говорения и думания, цель которой именно прикрыть свои манипулятивные эгоистические намерения в отношении бабушки.

Вернемся к трагедии выпавшего из окна второго этажа пятилетнего ребенка. Это девочка, и именно того «типа», который сейчас принято называть «принцесской», т.е. воспитанная в условиях безотказности для ее капризов.

Вывод, который мы можем сделать из обеих сюжетов с детьми: 1) «рефлексия для себя», т.е. двухплановый характер мышления (с целью получения эгоистической выгоды, но с желанием это скрыть) появляется в онтогенезе достаточно рано, и, скорее всего, это качество доступно 
животным (белка ловит другую белку на воровстве спрятанных орехов, делает новую закладку, наблюдает за белкой-воровкой и наказывает ее); 2) процесс становления реальной рефлексии, не «сработавшей» у девочки, выпавшей из окна, происходит совместно со становлением Супер-эго, и качественные характеристики рефлексии нельзя рассматривать вне качественных характеристик Супер-эго.

\section{Выво $\Delta ы$}

Осуществленное исследование позволило сформулировать следующие выводы:

1. рефлексия - это, с одной стороны, обязательный атрибут сознания, но также и его фактический демиург, строитель, и качественные характеристики сознания нельзя рассматривать вне качественных характеристик рефлексии;

2. при рассмотрении участия, места и роли рефлексии в конструкте личностной зрелости необходимо учитывать множество и количественных моментов ее приложения, от частных до общих, и характер работы самой рефлексии (психопат чаще примет один из полюсов интересующего его бинара и будет следовать ему неуклонно, полностью реализуя «тезис», использованный Высоцким: «Если я чего решил, то выпью обязательно!»; невротик будет постоянно колебаться между двумя альтернативами, не умея принять ни одну из них; относительно здоровый человек вынудит себя принять «единственно правильное» для себя решение, в целом понимая и величину жертвы другой альтернативы, но также и понимая, что почти всегда можно многое исправить), и то, какими средствами и способами она (рефлексия) осуществляется (один человек ограничится эмоционально обоснованным для себя выбором, другой будет искать пути научного анализа через поиск своего решения при учете множественности сомнений). Наконец, итогом рефлексии может быть мнение, убеждение, поступок, качества которых также неоднородны и неоднозначны.

\section{ЛИТЕРАТУРА}

1. Аникина В. Философские традиции изучения рефлексии в контексте решения проблем самопознания. // Развитие личности. М.: Изд-во Московского педагогического государственного у-та. 2010. №3. С.127-138.

2. Джейнс Дж. Сознание и голоса внутри. [Электронный источник] URL: http://transmission.lenin.ru/Jaynes-Consciousness.html (дата обращения 03.09.2020)

3. Карпов А.В. Рефлексия в структуре сознания. // Вестник Ярославского государственного университета им. П.Г. Демидова. Серия: Гуманитарные науки. 2012. №1(19). С. 6-12.

4. Лакан Ж. Стадия зеркала как образующая функция Я. [Электронный источник] URL: https://psychic.ru/articles/modern/modern64.htm (дата обращения 03.09.2020)

5. Локк Дж. Опыт о человеческом разумении. [Электронный источник] URL: https://nibiryukov.mgimo.ru/nb_russian/nbr_teaching/nbr_teach_library/ nbr_library_classics/nbr_classics_locke_an_essay_concerning_human_understanding_book-1.htm (дата обращения 03.09.2020)

6. Мареев С.Н. Рефлексивная природа сознания. // Эпистемология и философия науки. 2010. №26(4). С.35-52.

7. Миловидов В.А. Цитата как инструмент активизации рефлексии. // Понимание рефлексии в коммуникации, культуре, образовании. Всероссийская (с международным участием) научно-практическая конференция, посвященная памяти заслуженного деятеля науки, профессора, доктора филологических наук Г.И. Богина. 2019. Тверь: Тверской государственный университет. 2019. С.222-228.

8. Мышление. Понимание. Рефлексия. / Составители и отв. ред. А.А. Псикоппель, В.Р. Рокитянский, Г.П. Щедровицкий. М.: Наследие ММК. 2005.800 с.

9. Пацюкова Ю.А. Субъект воплощенный. Телесные границы субъективности: сравнительный анализ теории «интенциональной телесности» М. МерлоПонти и концепции аффективной субъективности Ж-Ф. Лиотара. // Социально-экономические исследования, гуманитарные науки и юриспруденция: теория и практика. Новосибирск: 000 «Центр развития научного сотрудничества». 2015. №3. С.124-136.

10. Росийчук Т.А. Развитие языка и речи в соотнесении с культурным психогенезом. // Актуальные вопросы речевого взаимодействия. Материалы Всероссийской научной конференции, посвященной юбилею профессора Л.А. Месеняшиной. 2019. Челябинск: ЧГУ. 2019. С.39-56.

11. Савчук В.В. Становление рефлексии. // Мысль: журнал Петербургского философского общества. 2010. Т.10. №2. С.41-56.

12. Сизикова Т.Э. Рефлексивное психологическое консультирование: монография. Новосибирск: Изд-во НГПУ. 2018.518 с.

13. Сударева Д.А. Проблема реальности в философии В.П. Руднева. // Исторические, философские, политические и юридические науки, культурология и искусствоведение. Вопросы теории и практики. Тамбов: 000 Издательство «Грамота. 2016. №3(65). С. 164-166.

14. Шаров А.С. Онтология рефлексии: природа, функции и механизмы. // Рефлексивные процессы и управление. 2005. №1. С.71-92.

15. Шеленговская К.О. Историко-логический анализ подходов к проблеме рефлексии в философских исследованиях. // Альманах современной науки и образования. Тамбов: 000 «Грамота». 2009. №1-2. С.178-180.

16. Шигабетдинова Г.М. Феномен рефлексии: границы понятия. // Вестник Нижегородского университета им. Н.И. Лобачевского. Серия: Социология. Психология. Философия. 2014. №2(1). С.415-422.

( Мачуха Александр Михайлович (aleksandrinfo@bk.ru), Васильева Ольга Семеновна (vos@sfedu.ru). Журнал «Современная наука: актуальные проблемы теории и практики» 